\title{
Economic Impact of the Florida Cultured Hard Clam Industry
}

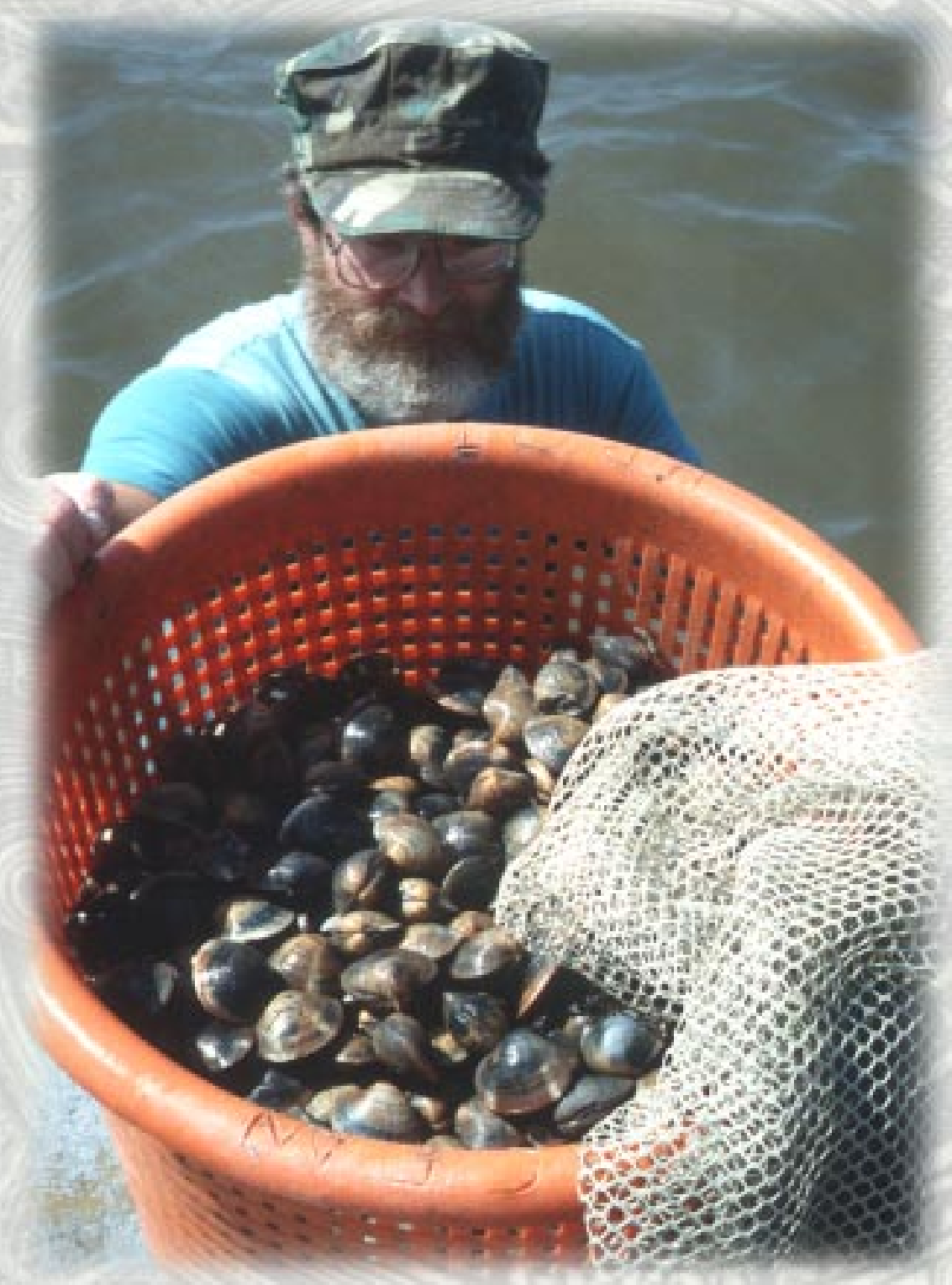

Effie Philippakos Charles Adams Alan Hodges
David Mulkey

Dorothy Comer

Leslie Sturmer 

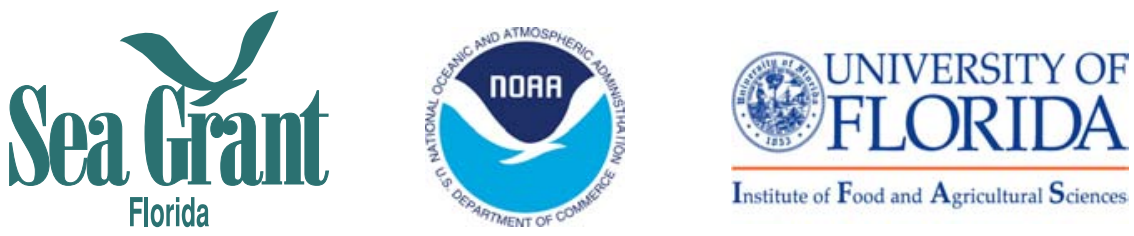

This technical paper was supported by the National Sea Grant College Program of the U.S. Department of Commerce's National Oceanic and Atmospheric Administration under NOAA Grant No. NA76RG-0120; and by the Institute of Food and Agricultural Sciences at the University of Florida. The views expressed herein do not necessarily reflect the views of the University of Florida, NOAA or any of its sub-agencies.

Additional copies are available by contacting Florida Sea Grant, University of Florida, PO Box 110409, Gainesville, FL, 32611-0409, (352) 392-2801. 


\section{Economic Impact of the Florida Cultured Hard Clam Industry}

Effie Philippakos

Charles Adams

Alan Hodges

David Mulkey

D orothy Comer

Leslie Sturmer

SG R 123

D ecember 2001

Project No. SGEP-12 


\section{Table of Contents}

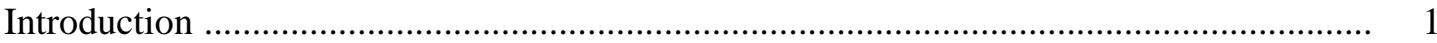

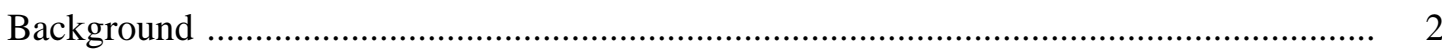

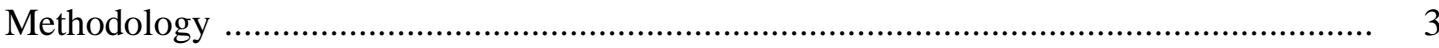

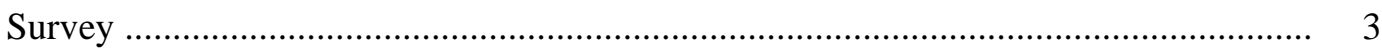

Economic Impact Analysis............................................................................... 4

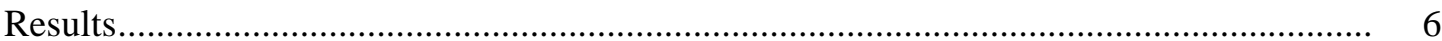

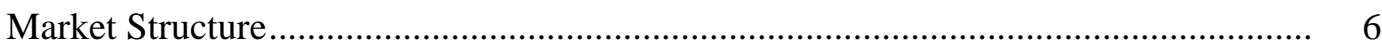

Source of Cultured Clams Handled ............................................................................ 7

Distribution of Cultured Clams ................................................................................... 8

Within Region Sales ............................................................................... 9

Between Region Sales ............................................................................... 9

Sales Outside of Florida............................................................................. 11

Prices Received for Cultured Clams .................................................................... 11

Economic Impact of Cultured Clams .................................................................... 13

Economic Impact of the Cultured Clam Industry to the Florida Economy ............ 13

Economic Impact of the Cultured Clam Industry on a Regional Basis .................. 13

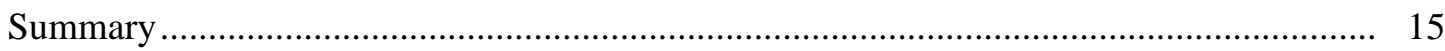

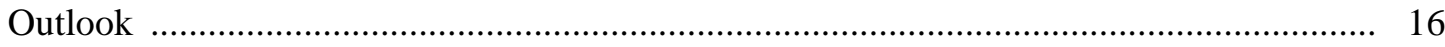

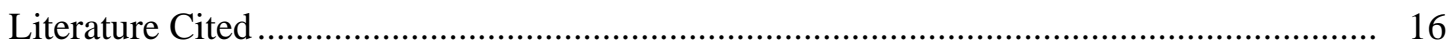

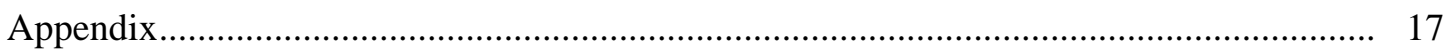




\section{List of Figures}

1. Market share of selected aquaculture commodity sales (farm-gate)

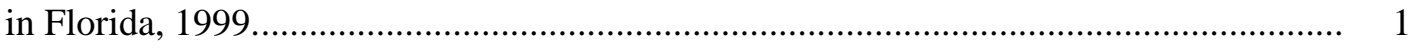

2. Farm-gate sales (nominal) of Florida cultured clams, 1993-1999. ................................. 2

3. Florida regions for the cultured hard clam study, 1999. ................................................ 4

4. Distribution and market share of cultured clam processing firms in Florida, by size class, based upon value of clams sold in 1999. ............................................. 6

5. Number of cultured hard clams supplied and distributed in Florida, 1999. .................... 7

6. Number of cultured clams (millions) obtained by firms, within and between regions, 1999. ..................................................................... 8

7. Distribution of cultured clam sales from each region, by marketing channel, 1999. ....... 10

8. Number of cultured clams (millions) sold within regions, 1999. .................................. 10

9. Number of cultured clams (millions) sold between regions, 1999. ................................ 11

10. Number of Florida cultured clams (millions) sold to buyers outside Florida, including international sales, by region of seller, 1999.

\section{List of Tables}

1. Number of cultured clams (millions) sold by region and destination, 1999.

2. Average prices (weighted by volume) received, by region and marketing channel, 1999.

3. Value of Florida cultured clam sales, 1999, by destination and marketing channel. ........ 13

4. State and regional economic impact estimates of the cultured hard clam industry, 1999

5. Regional value of cultured clam sales, by destination and marketing channel, 1999. 


\title{
Economic Impact of the Florida Cultured Hard Clam Industry
}

\author{
Effie Philippakos ${ }^{1}$, Charles Adams, Alan Hodges \\ D avid Mulkey, D orothy Comer, Leslie Sturmer
}

\section{INTRODUCTION}

Aquacultural products are an important sector within the Florida economy, with $\$ 86$ million in farm-gate sales in 1999 (FASS, 2000). Cultured hard clams (Mercenaria mercenaria) were the second largest component of these sales (Figure 1). Sales of cultured clams in Florida have experienced tremendous growth over the past 15 years. In 1989, sales of clams only represented less than one percent in market share of total aquacultural product sales. By 1999, clams represented 19 percent of the market share in sales. The tropical fish industry held 50 percent of aquaculture commodity sales in Florida and aquatic plants had 16 percent of the sales.

Several educational efforts during the 1991-98 period contributed to this growth in sales. The Job Training Partnership Act (JTPA) funded a demonstration and training program, known as Project OCEAN, that initially provided potential growers with information on the production, market preparation, marketing, and business aspects of clam culture. Subsequent programs, such as Project WAVE, Project CLAM and Project OAK HILL, trained additional growers. These projects have supplied the cultured clam industry with a firm foundation of technical support that has contributed to a steady growth in production and sales of Florida cultured clams. For example, farm-gate sales of cultured

\footnotetext{
${ }^{1}$ The authors may be contacted through the Department of Food and Resource Economics, University of Florida, PO Box 110240, Gainesville, FL, 32611-0240, (352) 392-1826.
}

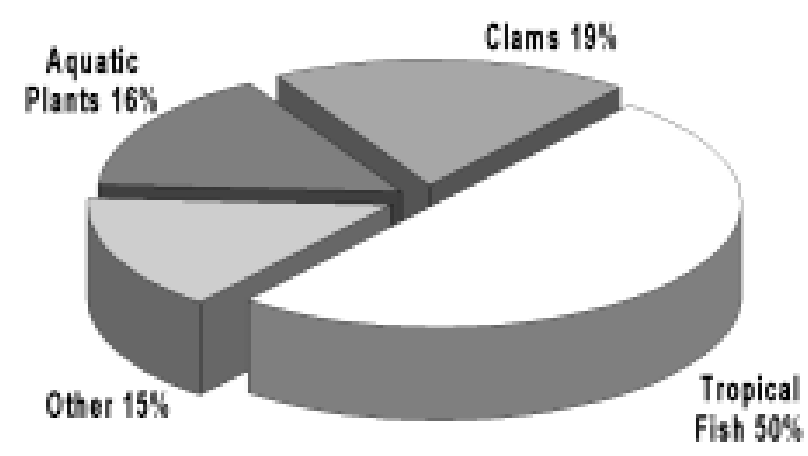

Figure 1. Market share of selected aquaculture commodity sales (farm-gate) in Florida, 1999. Source: Florida Agricultural Statistics Service.

clams were $\$ 3.7$ million in 1993. By 1999, sales of clams had grown to $\$ 15.9$ million (Figure 2).

Although the clam industry has grown dramatically over the 1993-1999 period, the economic impact of the industry on the region or state has not been estimated. Not only does the clam industry contribute in terms of employment and sales of products, it produces a greater economic benefit to Florida because of the economic activity it generates among the firms that provide inputs to the clam culture firms. In addition, employees within the clam industry generate economic activity when they spend their income on housing, food, and other goods and services. Thus, the economic benefits resulting from clam culture extend beyond the local culture area to the general Florida economy. 


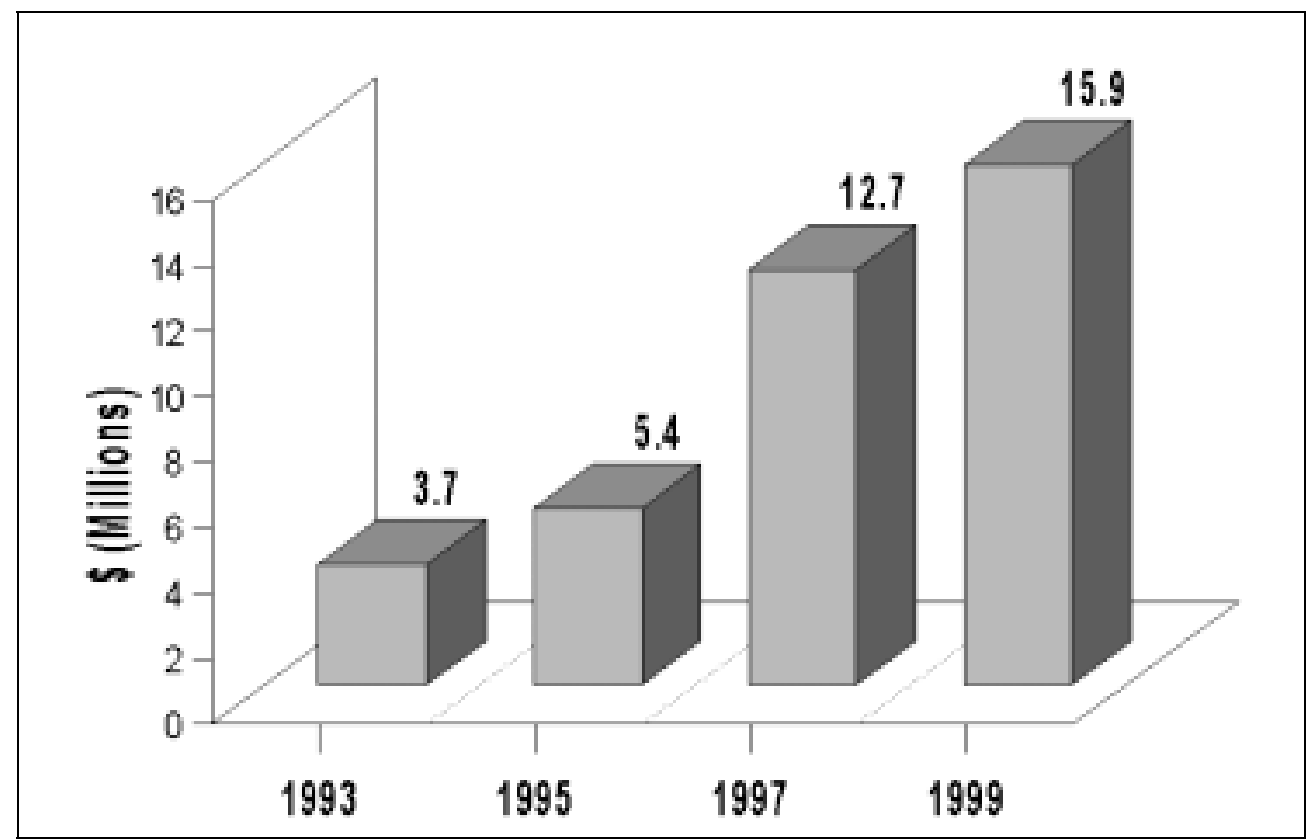

Figure 2. Farm-gate sales (nominal2) of Florida cultured clams, 1993-1999. Source: Florida Agricultural Statistics Service.

For the cultured hard clam industry to continue to thrive, it is essential that the water quality standards be high enough to allow clam production in current and future lease areas. Permitting and regulatory measures need to remain favorable for economically viable production of the clams. In addition, effective marketing efforts will allow for the industry to reach its full potential. Given the need for this support, it is essential that state and local decision-makers understand the value of Florida's cultured clam sales to the state's economy. This report represents the first attempt to document the economic importance of the rapidly growing cultured hard clam industry in Florida. The specific purposes of this report are to:

- Document the movement of clams through the various marketing channels (processor, wholesale, retail, restaurant, and consumer), both in terms of the number of clams and in terms of dollar value of sales;

- Identify the major sources of and markets for cultured clams to certified shellfish processors and wholesalers; and

\footnotetext{
${ }^{2}$ Sales value is measured in current dollars and is not adjusted for inflation.
}

- Estimate the broad economic impact to the regional and state economies.

\section{BACKGROUND}

The hard clam culture industry has a history extending back more than 20 years in Florida. Attempts to culture hard clams in Florida originated in the Indian River Lagoon during the late 1970s as a means to create an alternative supply source to fluctuating wild hard clam stocks. Techniques for producing seed clams had been developed during the 1950s; and the Harbor Branch Oceanographic Institution developed the early grow-out culture technologies during the 1980s. The development of the hard clam culture industry on the Gulf Coast of Florida began in the early 1990s, primarily through job retraining program efforts designed for displaced workers in the commercial fishing industry. Soon, cultured clam production in the Big Bend region increased dramatically, with industry growth rapidly shifting from the east coast to the west coast of Florida. There are currently about 600 leases comprising 1,600 acres in Florida. About 400 individuals are actively involved in commercially culturing hard clams. 
Hard clams are grown on coastal submerged lands leased from the State of Florida. Successful clam farming requires good quality water, free from bacterial and industrial contamination. The three distinct steps that characterize the culture process, each requiring a specific technology and set of inputs are: seed production, nursery, and grow-out. The seed production process occurs in land-based hatcheries. Brood stock clams are spawned in a controlled, indoor environment, and this is relatively capital intensive. Juvenile clams are kept in the hatchery until they reach a size where they can be transferred to a land-based or field nursery. There are about 12 hatcheries in the state.

The nursery component represents an intermediate step in the production process, and provides the seed clams with adequate food supply and protection from predators. Nurseries can be designed either as a land-based or field-based facility. Landbased nurseries are typically shallow raceways, whereas the field nurseries require the seed to be planted on a submerged lease in small-meshed bags. There are about 75 land-based nurseries in Florida. However, most growers opt to use a field-based nursery due to the space and capital requirements of the land-based system.

The seed clams are held in the nursery until they are ready to be planted into the grow-out system. Grow-out typically requires the nursery clams to be planted in soft-meshed polyester bags on the bottom. The clams are left there until they reach market size. The primary inputs into the process are the bags, seed clams, labor, boat fuel, and boat maintenance. After the clams are harvested, they are washed, graded by size, packed in shipping bags, and distributed by refrigerated transport to wholesale and retail buyers throughout Florida and the United States.

The grow-out process has been shown to be potentially profitable, if the business is properly managed and acceptable water quality conditions persist during the culture period. For example, a recent study by the University of Florida's Institute of Food and Agricultural Sciences (IFAS) has shown that a 2-acre grow-out facility operated under guidelines suggested by IFAS Extension can earn in excess of $\$ 30,000$ per year (Adams and van Blokland, 1995). Higher stocking densities can generate even more revenue. Although profit is obviously dependent on market price, the market for cultured hard clams has continued to be strong, even in the face of expanding production levels.

\section{METHODOLOGY}

\section{Survey}

A telephone survey was developed to collect information from all Florida processors and certified shellfish wholesalers (henceforth referred to as "firms") who handle hard clams within the state. The information solicited included the number of cultured clams handled, sources of clams, distribution channels through which the clams were sold, and prices that the firms received in each marketing channel.

A preliminary version of the questionnaire was developed and mailed to three firms to identify potential problems. The pre-tested survey was revised and subsequently mailed to the 53 Florida certified shellfish firms who were identified by the Florida Department of Agriculture and Consumer Services as handlers of Florida cultured hard clams. It is believed that this list of firms is complete and covers all firms that handle Florida cultured hard clams. There were 49 firms that actively sold Floridacultured clams in 1999.

The questionnaire (Appendix) was mailed to the firms with a cover letter that explained the objective of the study, assured the anonymity of respondents, and requested their cooperation when they were contacted by telephone later to complete the survey. Firms were assured that they would receive a copy of the results, but no other compensation or incentive was offered for completing the survey. The purpose of providing the firms with the survey prior to the telephone interview was to familiarize the respondents with the detailed economic information solicited by the survey and to allow them to compile the information in advance if possible. Approximately one week after the initial mailing, the firms were contacted by phone and solicited for their responses. Two firms mailed the completed questionnaire. Some firms required numerous callbacks, while some needed a personal visit to explain the purpose of the study. Such reluctance on the part of the survey participants is common when such pro- 


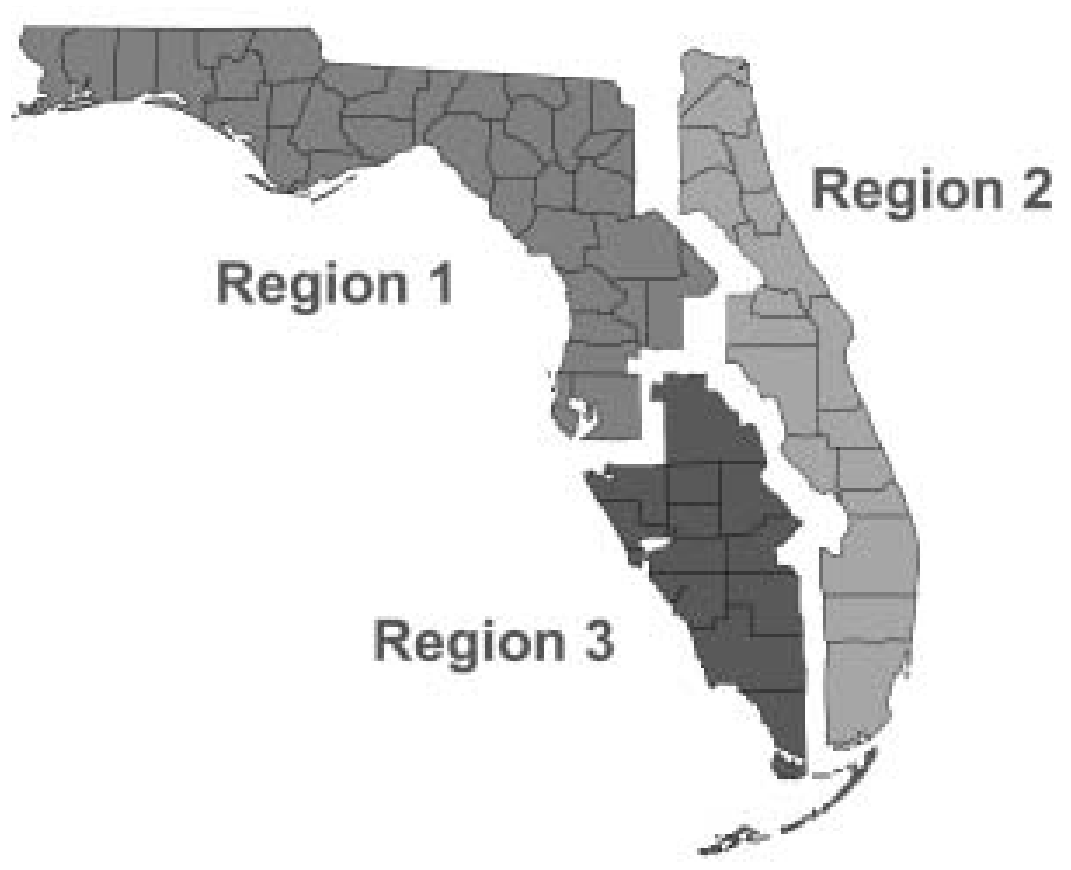

Figure 3. Florida regions for the cultured hard clam study, 1999.

quently sells these clams to a third wholesaler. These clams would be counted twice, first as a portion of sales of the firm that received them from a wholesale source and again when the third firm sells them. This would overstate the value of clam sales and inflate the economic impact of clam production. Clams obtained from a wholesaler and sold to restaurants, retailers, consumers or wholesalers outside the state of Florida were not part of the recirculation process and these sales were included in the firm's sales. After wholesale sales were adjusted to eliminate double counting, the value of clam sales for each firm was calculated by multiplying the number of clams sold in each marketing channel by the corresponding price the firm received from that marketing channel. The value

prietary information is requested. Two of the firms refused to participate in the study and an additional five firms could not be contacted. There were 42 firms that completed the survey, yielding an 85.7 percent total response rate for the survey. The seven non-responding firms individually represented small clam businesses with respect to sales generated.

For confidentiality reasons, the information collected was not identified as to individual firms; however, responses were identified according to the region within which the firm was physically located. The state was divided into three regions (Figure 3; a list of counties by region is provided in the Appendix). Region 1 covered the northwest portion of the state, from the Panhandle to Tampa. Region 2 encompassed the east coast, from Jacksonville to the Keys. Region 3 was made up of the counties in the southwestern portion of the state.

In order to avoid double counting, clams purchased from wholesalers and sold through Florida marketing channels were omitted from the present analysis. Wholesale firms represent both suppliers and buyers of clams. This structure presents the potential for counting clams sold more than one time. For example, assume a wholesale firm purchases clams from another wholesale firm and subse- of clam sales reported in this study only represents the aggregate sales of the 42 responding firms. Values were not extrapolated for the 7 non-responding firms.

\section{Economic I mpact A nalysis}

Florida's hard clam industry impacts the state economy in three primary ways. First, as direct effects, the industry generates output ${ }^{3}$, value added ${ }^{4}$, and provides employment and wages to employees. Second, clam processing and wholesaling firms require inputs in order to operate. For example, firms use electricity, fuel, ice, and other supplies. The demand for clams generates demand for the inputs into the processing of clams. The purchase of goods and services such as inputs from other industries sup-

\footnotetext{
${ }^{3}$ Output represents total sales revenues.

${ }^{4}$ Value added represents sales revenues less purchased inputs. Value added is a good indicator of the net contribution of an industry to the economy, since it reflects the increase in value from each stage of processing and marketing, and avoids double counting the sales of products from production sectors to the manufacturing and processing sectors which is inherent in the values for economic output.
} 
tries, referred to as indirect effects. Lastly, personal consumption expenditures by direct and indirect industry employees boost Florida's economy, known as induced effects. The sum of the direct, indirect, and induced effects yields total economic impacts.

An input-output (I-O) methodology was used to estimate the direct, indirect, and induced economic impacts of the cultured clam industry in Florida. Input-output analysis is a technique that captures the regional economic interdependence between different industries, households, and government institutions (Miller and Blair, 1985; Mulkey and Hodges, 2000). An underlying assumption of input-output analysis is that output or employment for a particular industry or region will generate predictable changes in other related sectors of the economy. These changes are measured by estimating the regional economic multipliers associated with the particular industry. A multiplier describes the economic activity that will be generated as a result of a change in final demand. The total multiplier takes into account the direct, indirect, and induced impact of this change in final demand as money is spent and respent, or "multiplied," within the local economy.

The input-output analysis was conducted using the IMPLAN PRO ${ }^{\text {TM }}$ software package. There are two components to the IMPLAN system. The database provides economic and socio-demographic descriptions for all United States counties across 528 economic sectors. The categorization of these sectors relies upon the US Department of Commerce's four-digit Standard Industrial Classification (SIC) system. The software component of the IMPLAN modeling system calculates, for a pre-defined study area, multipliers to assess economic impacts to the state. These multipliers are for economic output, total value added, employment, employee compensation, personal income, other proprietary income, and indirect business taxes. Multipliers are provided for direct, indirect, and induced impact effects. U.S. national data for 1998 was used to develop the complete inter-industry structural tables and coefficients, while data for all Florida counties was used to develop the economic impact of the clam industry on the state. The regional impacts were estimated using only the counties within the region being analyzed.

The IMPLAN database system includes a commercial fisheries category, and an initial analysis was completed using this basic sector. The model was then adjusted to reflect the specific characteristics of the Florida clam culture industry because a specific sector dedicated to clam culture does not exist in IMPLAN. These adjustments were based upon budgets for cultured hard clams as developed by Adams and van Blokland $(1995)^{5}$.

Total economic impacts were computed by applying the economic multipliers as follows:

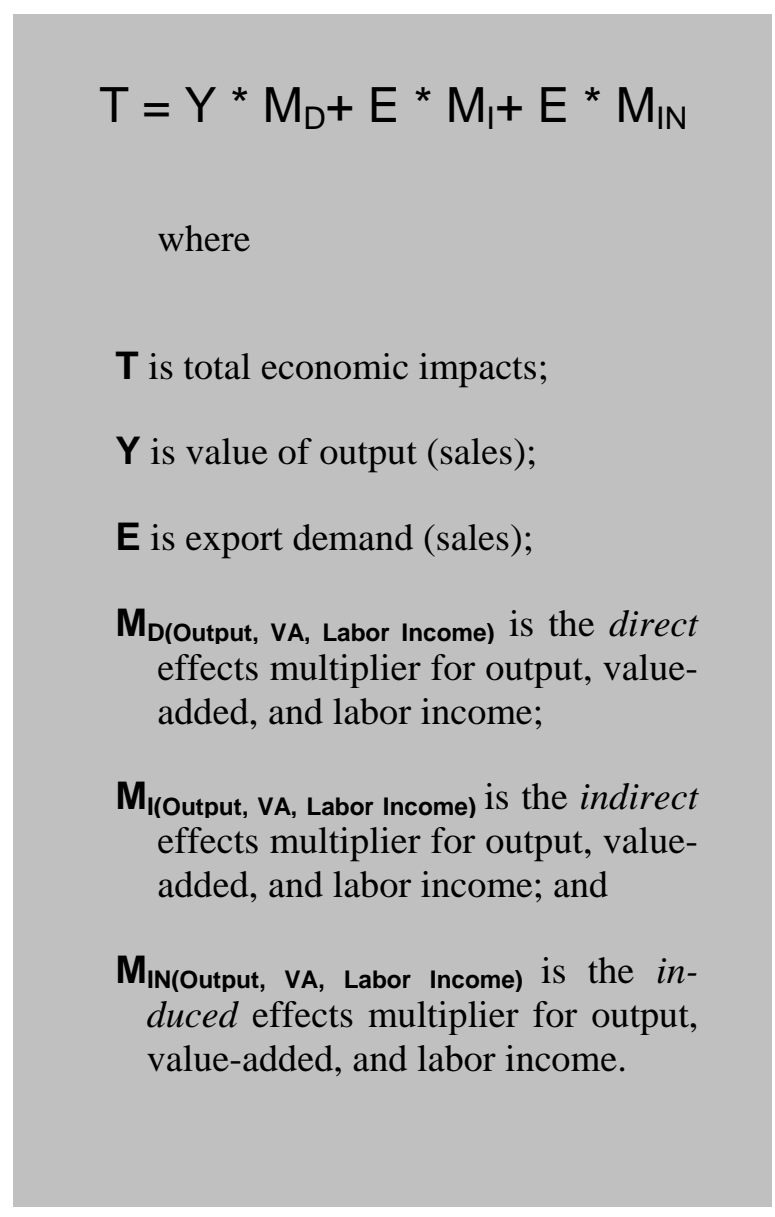

${ }^{5}$ The Adams and van Blokland report is based upon : "small scale commercial clam culture of hard clams." The majority of clam firms surveyed in this report are small-scale operations. Therefore the budgets of the Adams and van Blokland incorporated in this study are representative of the typical clam firm responding in this survey. 


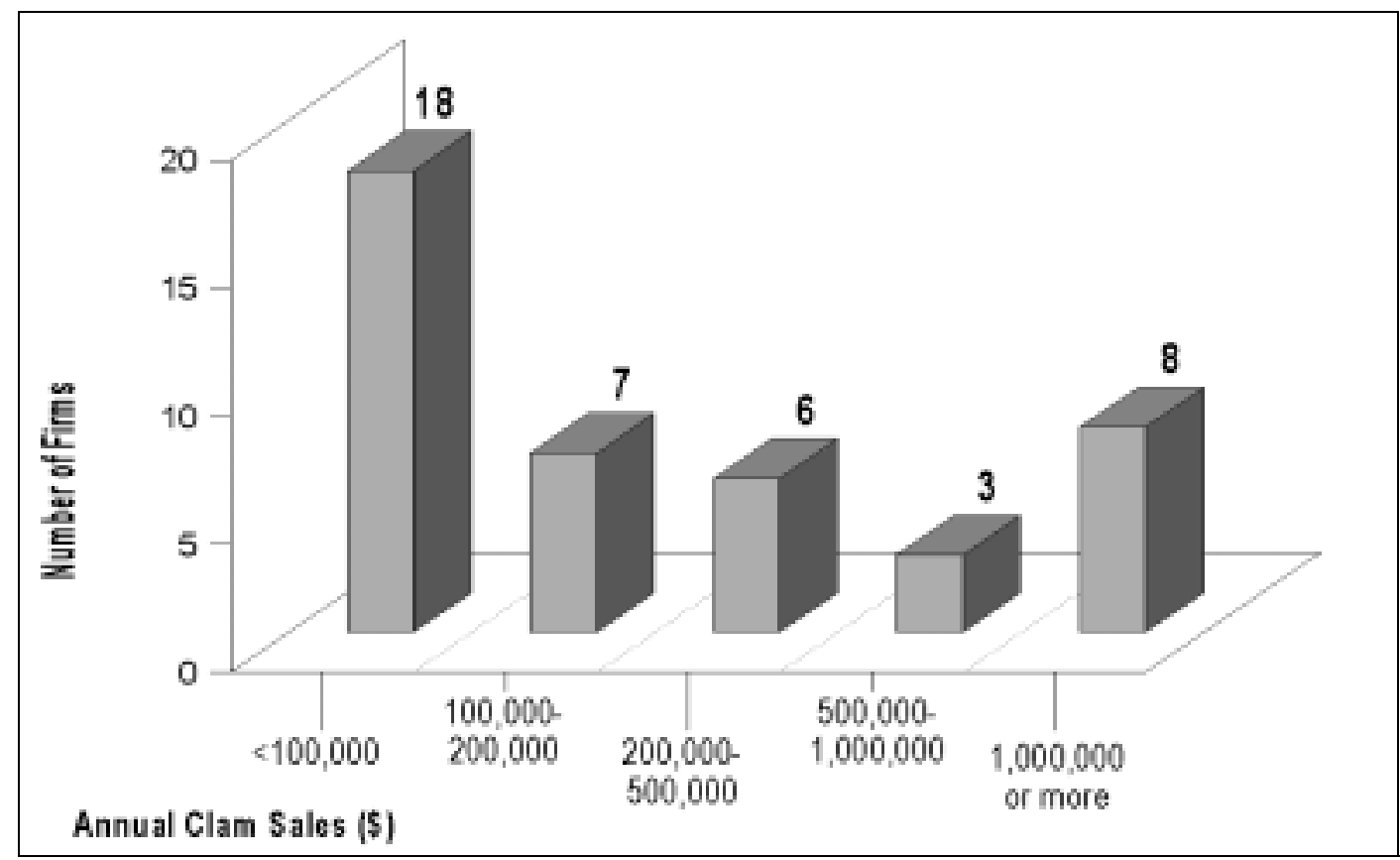

Figure 4. D istribution and market share of cultured clam processing firms in Florida, by size class, based upon value of clams sold in 1999.

\section{RESULTS}

The results section will begin with an examination of the market structure of the Florida cultured hard clam industry. Then the sources of clams will be examined, both in terms of the origin (personal lease, other growers, or wholesale firms) and regional source. The distribution and prices of cultured clams by market channel and location will be discussed. Finally, the economic impact of the Florida cultured clam industry will be estimated for the state and for each region.

\section{Market structure}

In 1999, approximately 143.1 million clams were sold by Florida clam processing or wholesale firms. The value of these sales was over $\$ 21.8$ million. The sales volume of the individual clam processing or wholesaling firms varied considerably across Florida. The annual sales for the smallest firm was 2000 clams, worth $\$ 208$, while the largest firm handled almost 25.5 million clams, worth $\$ 3.8$ million in sales in 1999. There were 18 firms that had less than $\$ 100,000$ a year in clam sales, which represents the largest size class of firms (Figure 4).
Firms with sales exceeding $\$ 1,000,000$ a year represent the second largest size class of firms.

Market share represents the proportion of the total market controlled by an individual firm or group of firms. The combined clam sales of the 18 smallest firms were valued at $\$ 670,000$ and represented 3.1 percent of the total market. The average market share held by each of these firms was less than 0.2 percent of the market. Firms with sales from $\$ 100,000$ to $\$ 200,000$ had a market share each that averaged 0.6 percent of the total market and their combined sales were $\$ 849,000,3.9$ percent of the market. A firm must have between $\$ 200,000$ and $\$ 500,000$ in sales in order to have a market share larger than one percent (1.5 percent per firm) but the combined sales of these firms was not quite $\$ 2$ million, or 9.0 percent of the market. Combined, the 31 firms in the smallest three size classes captured only 15.9 percent of the total clam market. Even the larger firms, those with more than $\$ 500,000$ in sales each year, did not have large market shares individually. The three firms with sales between $\$ 500,000$ and $\$ 1$ million averaged a market share of 3.3 percent each. The eight firms with more than $\$ 1$ 


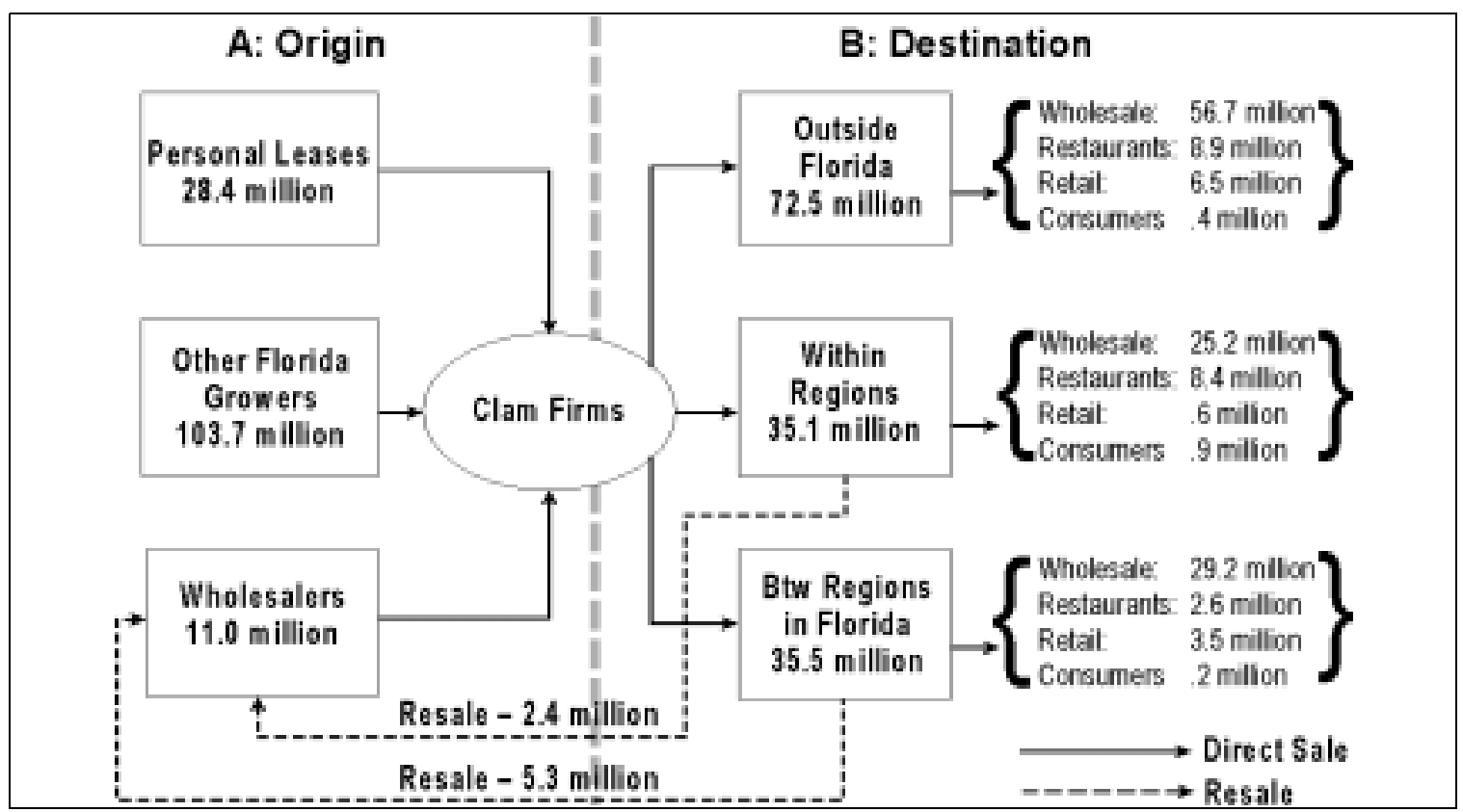

Figure 5. Number of cultured hard clams supplied and distributed in Florida, 1999.

million in sales averaged 9.3 percent of market share per firm. The largest market share held by any single firm was 17.6 percent. Firms with more than $\$ 500,000$ in sales had combined sales of $\$ 18.4$ million, or 84.4 percent of the Florida market.

\section{Source of Cultured Clams Handled}

Firms received Florida-cultured clams from three sources: their own personal leases, other Florida growers, and other wholesalers (Figure 5, side A). Statewide, other growers provided 103.7 million (72.5 percent) of clams sold; personal leases provided 28.4 million (almost 20 percent); and other wholesalers account for the remaining 11 million clams (7.7 percent). About 7.7 million clams obtained from wholesalers were sold to other wholesalers, either within the firm's region (2.4 million) or in another region in Florida (5.3 million). These 7.7 million clams were not considered in the value of the receiving firms' sales to avoid double counting (see discussion on page 4).

Firms were asked to identify the number of clams that they received from their own region and from each of the other Florida regions. Clam firms in all three regions received most of their clams from sources within their own region (Figure 6). For example, of the 92.3 million clams handled by firms in Region 1 (Northwest Florida), 87.27 million were obtained within Region 1. Firms in Region 2 (East Florida Coast) obtained 24.57 million clams from sources in Region 2. Region 3 (Southwest Florida) firms obtained 17.5 million clams from within Region 3, most of them (15.52 million) from growers.

The volume of clams obtained from outside a specific region varied by region. For example, firms in Region 1 obtained 4.98 million clams (5 percent) from Regions 2 and 3 combined (Figure 6). Of these, 630,000 came from Region 2 and 4.35 million from Region 3. On the other hand, firms in Region 2 obtained 8.72 million (26 percent) of their clams from outside their own region. Of these, 7.66 million came from Region 1 and 1.06 million from Region 3. Firms in Region 3 purchased 82,000 clams ( 0.5 percent) from outside their own region $(2,000$ from Region 1 and 80,000 from Region 2).

Firms in each region obtained the majority of their clams from growers in their own region. Volumes of clams acquired from their own leases or other wholesalers were less important. For example, firms in Region 1 obtained 64.6 million clams from growers in Region 1, while growers in Regions 2 and 3 provided only 0.26 million and 1.13 million 


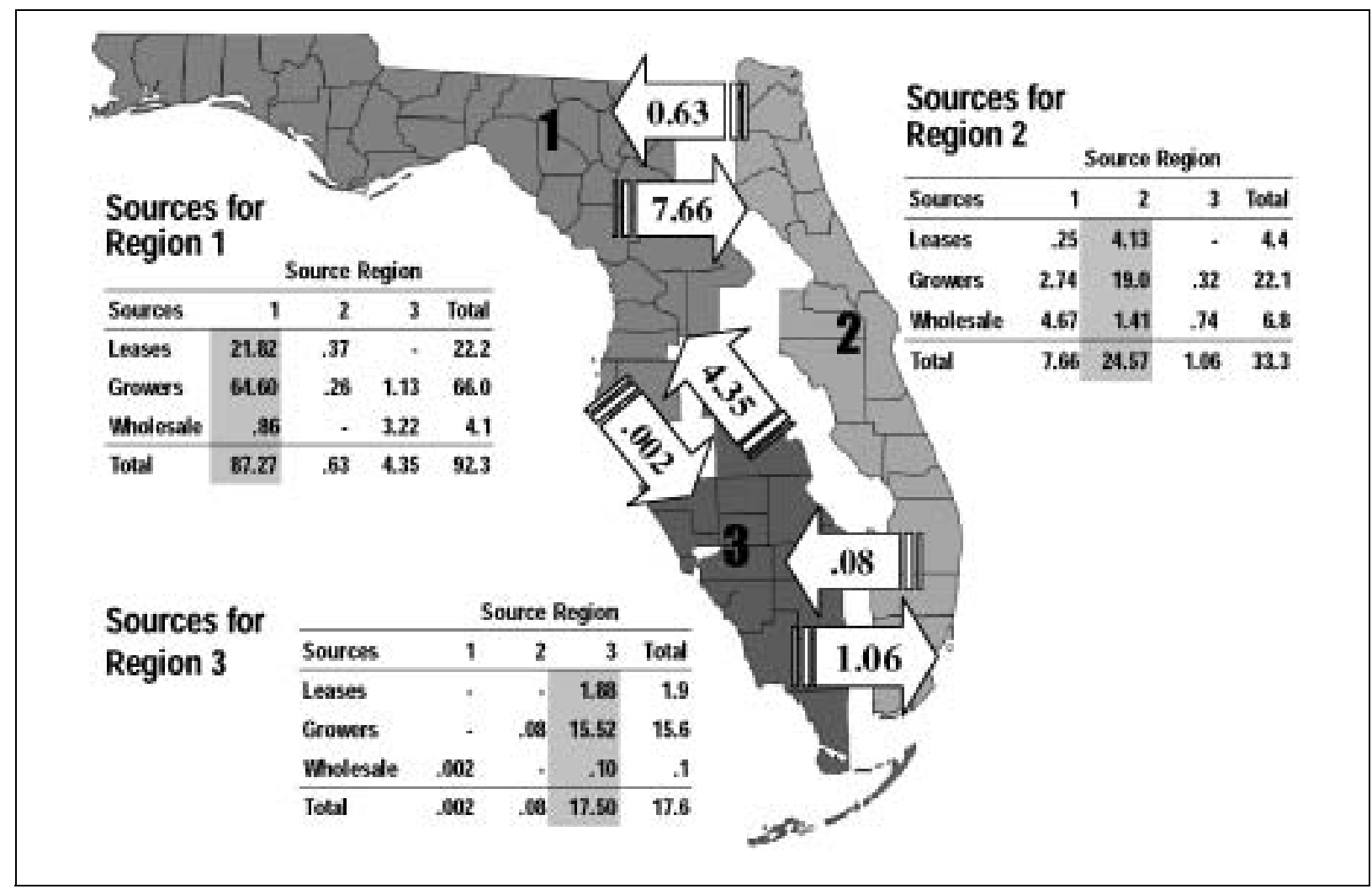

Figure 6. Number of cultured clams (millions) obtained by firms, within and between regions, 1999. Arrows indicate volumes moving between the respective regions. The totals may not sum due to rounding.

clams. Firms in Region 1 obtained 860,000 clams from the other wholesalers in Region 1, yet acquired 3.22 million clams from other wholesalers in Region 3. Firms in Region 2 obtained 19 million from growers in Region 2 and 3.06 million clams from growers in Regions 1 and 3 combined. The majority of the clams that firms in Region 2 obtained from wholesalers (4.67 million) came from wholesalers in Region 1. Firms in Region 3 obtained the majority of their product from growers, other wholesalers, and their own leases located in Region 3.

\section{Distribution of Cultured Clams}

Florida certified shellfish processors within the state of Florida sold 143.1 million cultured clams in 1999 (Table 1). Almost 51 percent (72.5 million) of the clams were sold outside of Florida, including domestic and international destinations (Figure 5, side B). The remaining 70.6 million (49 percent) were sold within Florida, 35.1 million of them within the selling firm's region and 35.5 million to other regions within the state.

During 1999, Region 1 sold 92.3 million clams. Region 2 sold 33.3 million and Region 3 sold 17.6 million clams (Table 1). The regions differed in terms of the proportions their respective firms sold within the region, to other regions within Florida, and outside of Florida, including international sales. Firms in Region 1 sold 24 percent of the clams they handled locally (within their own region), 29 percent to other regions in Florida, and 47 percent outside the state. Firms in Region 2 distributed almost 36 percent within their own region and 58 percent outside of Florida. Firms in this region sold only 6 percent to other regions within Florida. Firms in Region 3 also sold more than half their clams outside of Florida (55 percent), 6 percent locally, and 39 percent to other regions in Florida.

Clam sales were distributed through four major market channels: wholesalers, retailers, restaurants, 


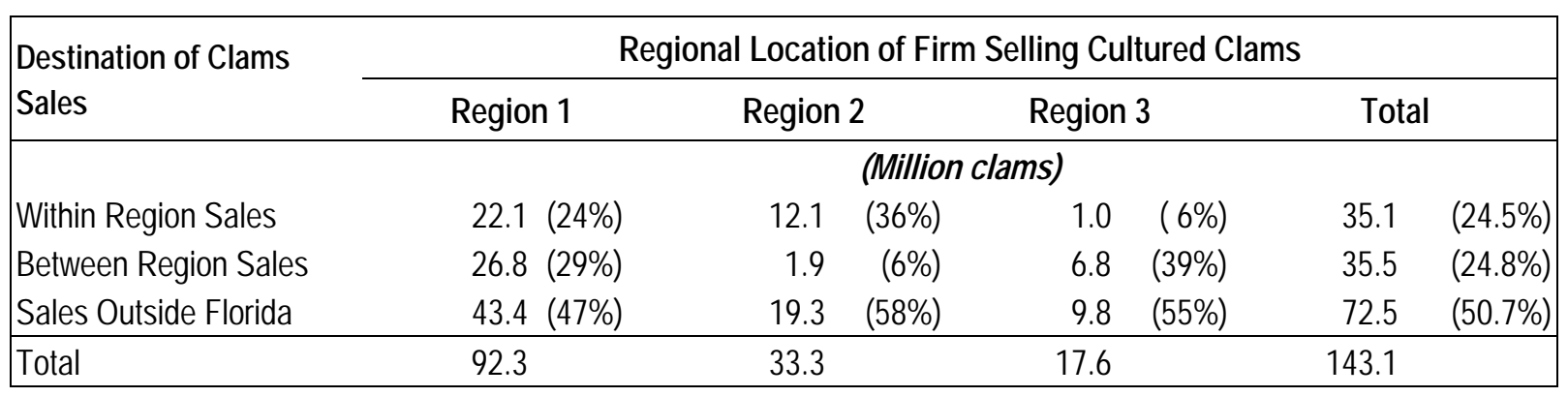

Table 1. Number of cultured clams (millions) sold by region and destination, 1999.

and consumers (Figure 7). Sales to wholesalers dominated both Regions 1 and 3. In Region 1, almost 91 percent of sales were to wholesalers; 4.1 percent of the sales were to restaurants, and 5.1 percent to retailers. About a tenth of a percent of clams were sold directly to consumers by firms located in Region 1. Region 3 had a sales pattern similar to that of Region 1. Over 78 percent of clam sales were to wholesalers; 10 percent were to restaurants, 8.3 percent to retailers, and 3.3 percent directly to consumers. Region 2 differed from the other two regions in that more sales were to restaurants (43 percent). Wholesalers still represented a significant marketing channel, with 41.1 percent of the sales. Retail sales were 13.3 percent. For firms in Region 2, direct sales to consumers (2.6 percent) were slightly less than in Region 3, but greater than Region 1.

Within Region Sales. The number of clams sold within the respective regions in Florida totaled 35.1 million (Figure 5, Side B). Of these, the number of clams sold to the four marketing channels differed with respect to regional location of the clam firm. Of the 22.1 million clams sold by firms in Region 1 to buyers within Region 1 (Table 1), wholesalers purchased 90 percent (19.93 million) and the remaining 10 percent of clams were sold to restaurants (1.95 million), retailers $(110,000)$, and consumers $(70,000)$ (Figure 8).

Firms in Region 3 sold one million of their clams within their own region (Table 1). Again, sales to wholesalers dominated the market (Figure 8). Wholesalers purchased 740,000 clams (73 percent). Restaurants bought 190,000 clams (19 percent); retailers received 80,000 clams (8 percent), and consumers purchased less than one-tenth of one percent.

The distribution of clams among the marketing channels differed in Region 2 from the other two regions. Firms in Region 2 marketed 12.1 million clams within the region; however, a larger proportion went to restaurants and consumers (Table 1). Firms sold 6.25 million clams (52 percent) of these to restaurants and 4.52 million clams (37 percent) to wholesalers (Figure 8). Retailers purchased almost 430,000 clams (4 percent) and consumers bought about 880,000 clams ( 7 percent). The dominance of restaurants and consumers in this region is plausible, given the tourism and population density of the region.

Between Region Sales. The number of clams sold by firms in one region to another totaled 35.5 million (Table 1). Wholesalers in all three regions were the dominant destination for the between region sales (Figure 9). Region 1 sold 21.54 million clams (80.5 percent) and Region 3 sold 5.85 million clams (85.8 percent) to wholesalers in other regions. Firms in Region 2 sold 1.82 million clams (96.5 percent) to wholesalers in other regions. For Region 1, retailers in other regions represented the second most important marketing channel (3.37 million clams). However, sales to restaurants were the next most important marketing channel for inter-regional sales by firms in Regions 2 and 3 (58,000 and 708,000 clams, respectively). Clam firms in Regions 1 and 2 did not sell any clams to consumers outside their region, whereas firms in Region 3 sold 158,000 clams (2.3 percent) to consumers. 


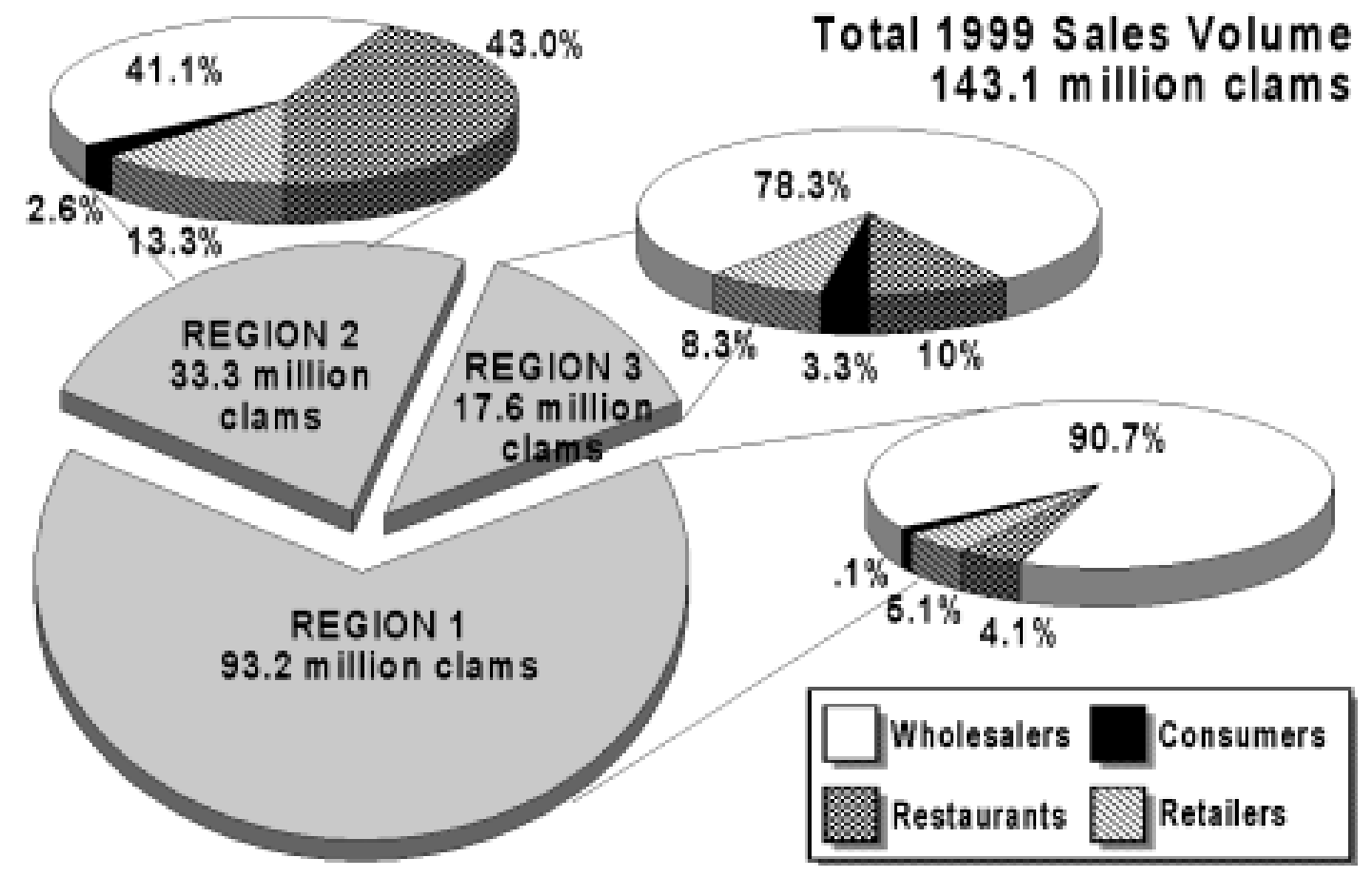

Figure 7. D istribution of cultured clam sales from each region, by marketing channel, 1999.

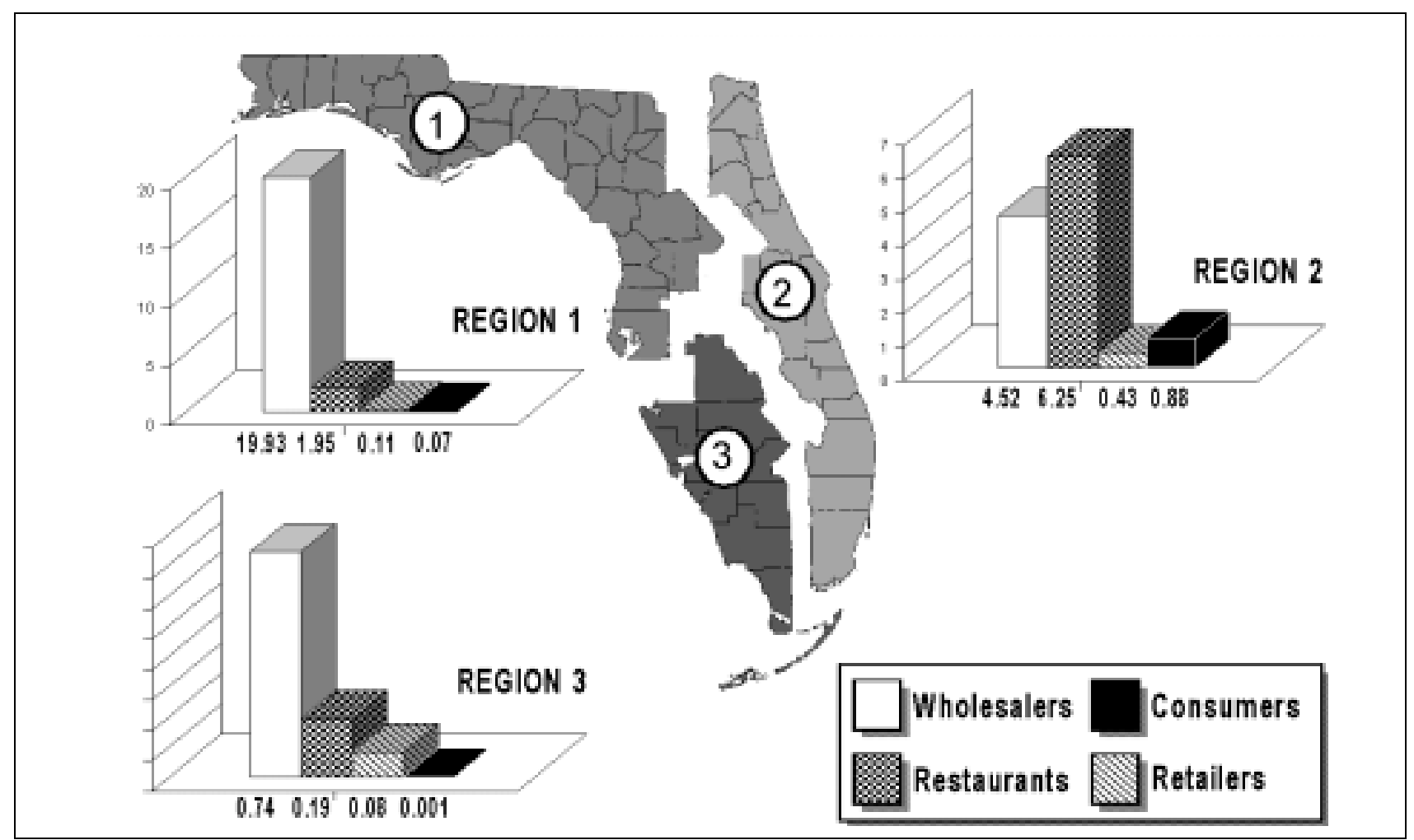

Figure 8. Number of cultured clams (millions) sold within regions, 1999. 


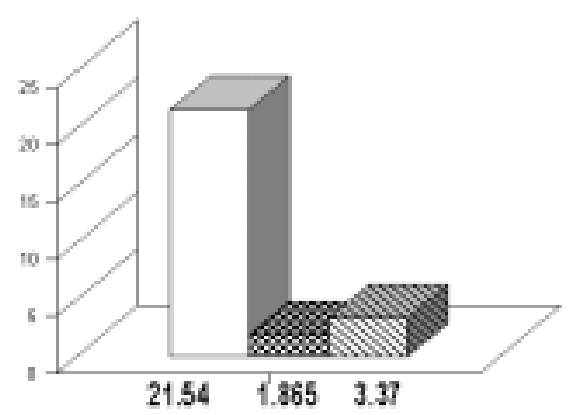

Sales by firms in Region 1

to Regions 2 and 3

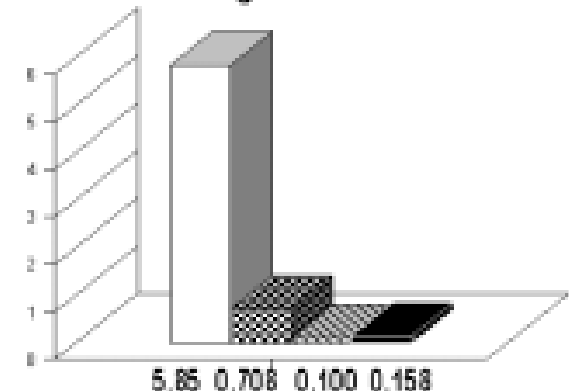

5.850 .7080 .1000 .158

Sales by firms in Region 3 to Regions 1 and 2

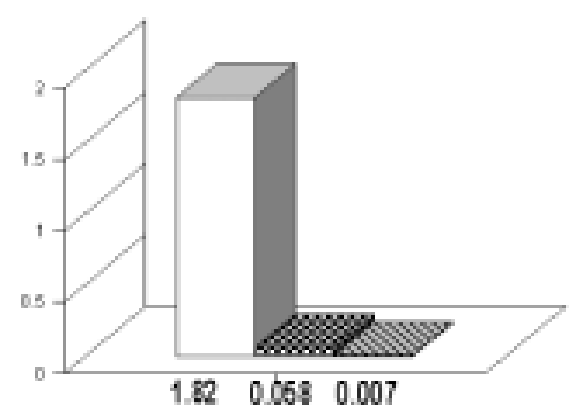

Sales by firms in Region 2 to Regions 1 and 3

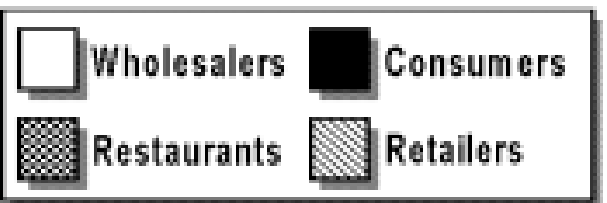

Figure 9. Number of cultured clams (millions) sold between regions, 1999.

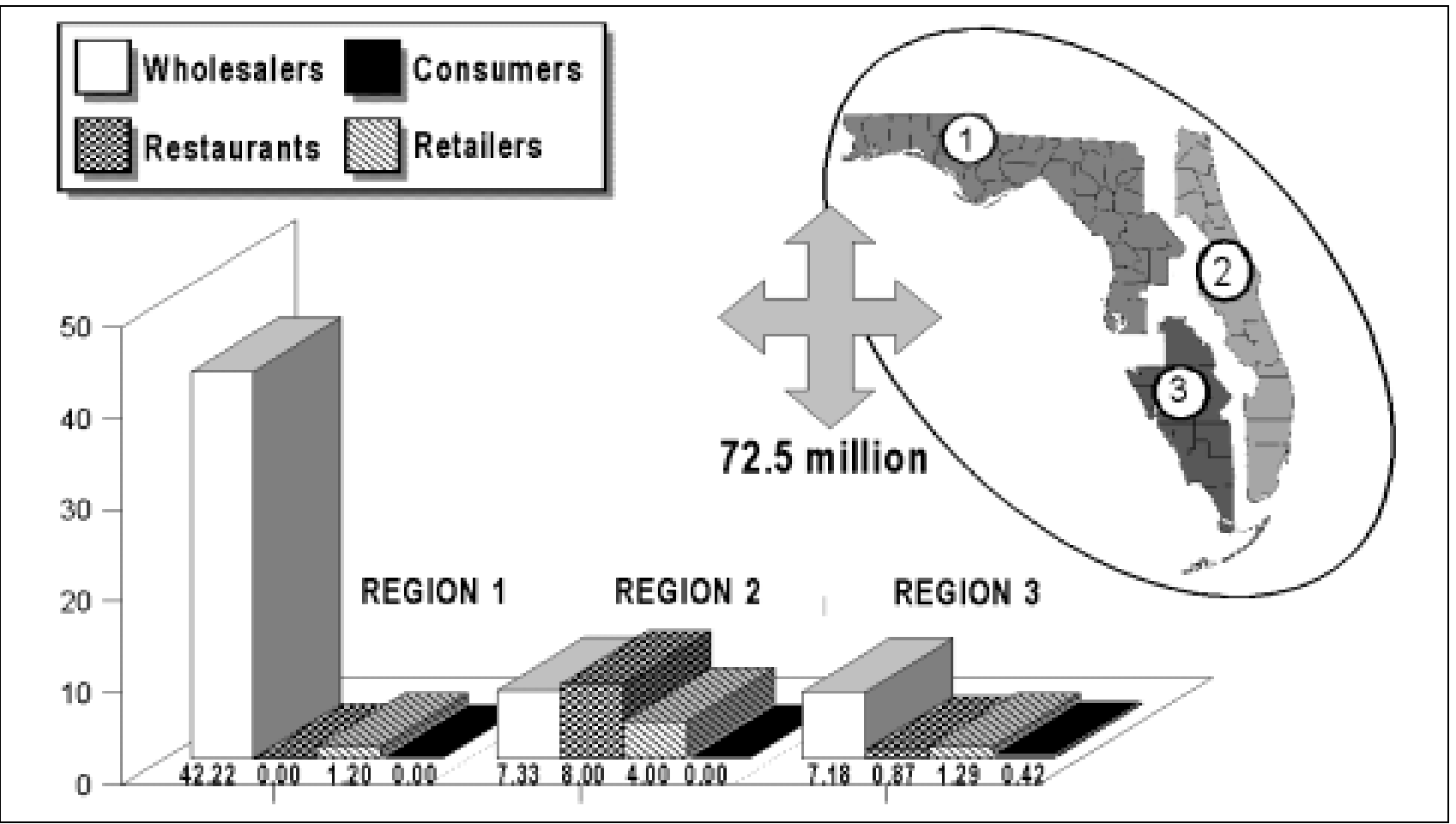

Figure 10. Number of Florida cultured clams (millions) sold to buyers outside Florida, including international sales, by region of seller, 1999. 


\begin{tabular}{|c|c|c|c|c|}
\hline & Region 1 & Region 2 & Region 3 & $\begin{array}{c}\text { Average } \\
\text { All Regions }\end{array}$ \\
\hline \multicolumn{5}{|l|}{ Wholesale } \\
\hline Within regions & 0.14 & 0.14 & 0.16 & 0.14 \\
\hline Between regions & 0.15 & 0.15 & 0.14 & 0.15 \\
\hline Out-of-State & 0.19 & 0.15 & 0.18 & 0.18 \\
\hline Overall & 0.17 & 0.14 & 0.16 & 0.17 \\
\hline \multicolumn{5}{|l|}{ Restaurant } \\
\hline Within regions & 0.19 & 0.14 & 0.20 & 0.16 \\
\hline Between regions & 0.18 & 0.24 & 0.20 & 0.19 \\
\hline Out-of-State & $N / A$ & 0.12 & 0.20 & 0.13 \\
\hline Overall & 0.18 & 0.13 & 0.20 & 0.15 \\
\hline \multicolumn{5}{|l|}{ Retail } \\
\hline Within regions & 0.19 & 0.20 & 0.19 & 0.20 \\
\hline Between regions & 0.13 & 0.24 & 0.17 & 0.13 \\
\hline Out of State & 0.16 & 0.12 & 0.19 & 0.14 \\
\hline Overall & 0.14 & 0.13 & 0.19 & 0.14 \\
\hline \multicolumn{5}{|l|}{ Consumer } \\
\hline Within regions & 0.21 & 0.25 & 0.26 & 0.24 \\
\hline Between regions & $N / A$ & N/A & 0.22 & 0.22 \\
\hline Out of State & N/A & N/A & 0.22 & 0.22 \\
\hline Overall & 0.21 & 0.25 & 0.22 & 0.23 \\
\hline
\end{tabular}

T able 2. Average prices (weighted by volume) received, by region and marketing channel, 1999.

Sales Outside of Florida. The total number of clams sold outside of Florida (domestic and international sales) was 72.5 million (Figure 10). In terms of these export sales, firms in Region 2 distributed their clams quite differently from those in Regions 1 and 3. Region 2 sold 8.0 million clams (41.4 percent) to restaurants and 7.33 million clams (37.9 percent) to wholesalers outside of Florida. Firms in Regions 1 and 3 attributed a greater percentage of their out-of-state sales to wholesalers. For example, Region 1 provided 42.22 million clams (97.2 percent) to wholesalers outside Florida, while Region 3 distributed 7.18 million clams (73.6 percent) to wholesalers outside the state. Region 3, like Region 2, sold clams to out-of-state restaurants, but Region 1 did not. A larger proportion of Region 3 out-ofstate sales (1.29 million clams or 13.2 percent), however, went to retailers who were located out-ofstate. Only Region 3 made sales to out-of-state consumers (420,000 clams, or 4.3 percent). These sales may represent mail-order sales, but no information exists to verify whether or not this is the case.

\section{Prices Received for Cultured Clams}

Clam firms reported the prices they received in each region by each market channel. Average prices, weighted by volume, were calculated for each region and each destination. (Note that any regional variations in prices received for clams may reflect the different sizes of clams produced per region. Variable clam sizes sell at different prices, which is not addressed in this study.) Overall, the weighted average price of clams across all regions and market channels in 1999 was $\$ 0.16$ per clam.

Wholesale prices ranged from $\$ 0.14$ per clam to $\$ 0.19$ per clam (Table 2). Wholesalers within Florida paid, on average, between $\$ 0.14$ and $\$ 0.16$ per clam, both when purchasing from a local firm or a firm in another region. Overall, out-of-state wholesalers paid an average of $\$ 0.18$ per clam; however, firms in Region 2 received an average of $\$ 0.15$ per clam from out-of-state wholesalers.

Restaurant prices were considerably more variable than wholesale prices. Restaurant buyers within Florida paid between $\$ 0.14$ and $\$ 0.24$ per clam, with an overall average price of $\$ 0.15$ per clam. 
Firms in Region 2 had the highest restaurant price with an average of $\$ 0.24$ per clam received from restaurants in other regions, as well as the lowest average price ( $\$ 0.12$ per clam) from out-of-state restaurants. Clam firms in Region 3 received $\$ 0.20$ per clam from out-of-state restaurant buyers in all locations.

Statewide, Florida retailers also paid between $\$ 0.13$ and $\$ 0.24$ per clam, with an overall average of $\$ 0.14$ per clam. Again, firms in Region 2 received the highest average price from buyers outside their own region as well as the lowest average price from out-of-state buyers. Prices received by firms in Region 3 were the least variable, ranging from $\$ 0.17$ to $\$ 0.19$ per clam.

Consistent with general expectations, consumers paid the highest price for clams. Consumers overall paid an average of $\$ 0.23$ per clam, ranging from $\$ 0.21$ per clam in Region 1 to \$0.26 in Region 3 . Region 3 was the only region that sold clams to consumers outside its region. Consumers within Region 3 paid $\$ 0.26$ per clam, while consumers from outside Region 3 paid 4 cents less per clam.

\section{Economic Impact of Cultured Clams}

Florida clam firms had $\$ 21.84$ million in sales of hard cultured clams to wholesalers, restaurants, retailers, and consumers in 1999 (Table 3). A total of $\$ 9.46$ million of clam sales were to buyers within Florida (wholesalers, restaurants, retailers, and consumers) and $\$ 12.38$ million in sales were to buyers outside Florida, including international buyers. Wholesale and restaurant buyers were the most important markets, both in-state and out-of-state, for Florida clam firms. Retail buyers and direct sales to consumers were significantly less important.

However, the \$21.84 million in sales of Florida cultured hard clams represents only the direct economic output of the clam wholesale industry. The economic impact to the Florida economy resulting from the hard clam culture industry requires a more complete assessment of the indirect and induced, as well as direct impacts to include the broad economic impacts associated with the hard clam culture industry for each region and the state as a whole.

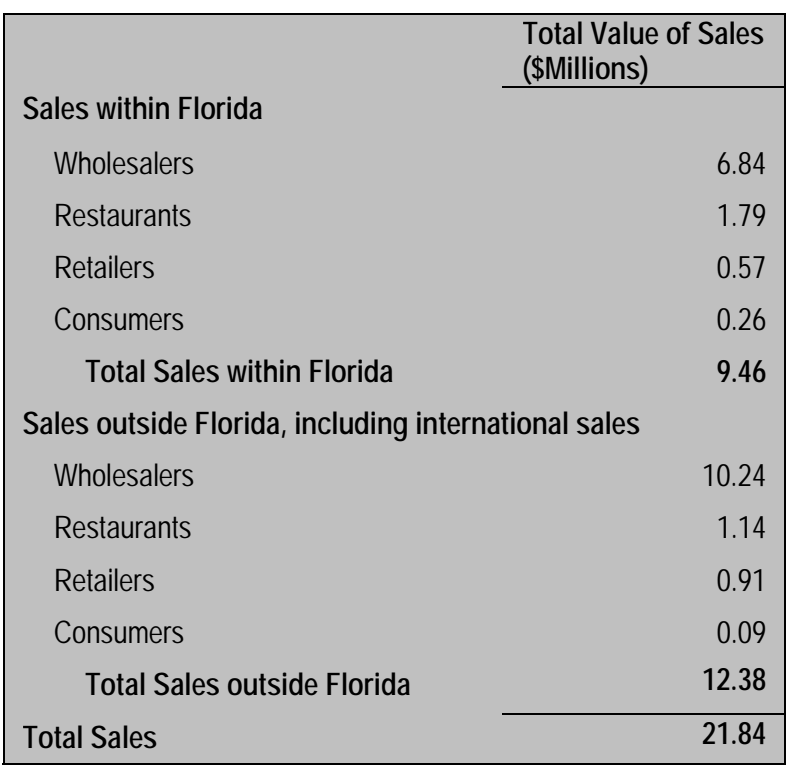

Table 3. Value of Florida cultured clam sales, 1999, by destination and marketing channel.

Economic Impact of the Cultured Clam Industry to the Florida Economy. The total economic impacts of the cultured clam industry to the Florida economy include $\$ 33.9$ million in output, $\$ 9.0$ million in labor income, and \$12.1 million in value added (Table 4). The direct economic impacts accounted for 64 percent of total output impacts, 43 percent of total labor income impacts, and 39 percent of total valueadded impacts to the Florida economy. The indirect economic impacts represented 14 percent of total output impacts, 23 percent of labor income impacts, and 21 percent of value-added impacts. The induced effects accounted for 22 percent of total output impacts, 34 percent of labor income impacts, and 40 percent of value-added impacts.

Economic Impact of the Cultured Clam Industry on a Regional Basis. It is important to recognize the sum of economic impacts by Regions 1,2 , and 3 will exceed the economic impacts of the state of Florida (the geographical entity comprised of Regions 1, 2, and 3). Exports by Region 1 include sales of goods and services to Regions 2 and 3, in addition to outside Florida (domestic and international) sales. The same characterization follows for exports by Regions 2 or 3 . Since exports by Regions 1, 2, or 3 will include between-region, national, and international sales, the collective sum of economic impacts 


\begin{tabular}{|c|c|c|c|c|}
\hline \multirow{2}{*}{ State of Florida } & \multirow{3}{*}{$\begin{array}{c}\text { Direct Effects } \\
21.8\end{array}$} & \multirow{3}{*}{$\begin{array}{c}\text { Indirect Effects } \\
4.7\end{array}$} & \multicolumn{2}{|c|}{ Induced Effects Total Effects } \\
\hline & & & & \\
\hline Output & & & 7.3 & 33.9 \\
\hline Labor Income & 3.9 & 2.1 & 3.1 & 9.0 \\
\hline Value Added & 4.7 & 2.6 & 4.8 & 12.1 \\
\hline \multicolumn{5}{|l|}{ Region 1} \\
\hline Output & 14.8 & 4.5 & 4.6 & 24.0 \\
\hline Labor Income & 2.5 & 1.9 & 2.1 & 6.5 \\
\hline Value Added & 3.1 & 2.5 & 3.3 & 8.8 \\
\hline \multicolumn{5}{|l|}{ Region 2} \\
\hline Output & 4.1 & 0.7 & 0.8 & 5.5 \\
\hline Labor Income & 0.8 & 0.3 & 0.3 & 1.4 \\
\hline Value Added & 1.0 & 0.4 & 0.5 & 1.9 \\
\hline \multicolumn{5}{|l|}{ Region 3} \\
\hline Output & 3.0 & 1.1 & 0.8 & 4.9 \\
\hline Labor Income & 0.5 & 0.5 & 0.4 & 1.4 \\
\hline Value Added & 0.6 & 0.6 & 0.6 & 1.8 \\
\hline
\end{tabular}

Table 4. State and regional economic impact estimates of the cultured hard clam industry, 1999.

by Regions 1, 2, and 3 will be greater than economic impacts associated with the broad regional definition of the state of Florida. This is because the sum of exports by Regions 1, 2, and 3 include interregional and out-of-state sales, whereas exports attributed to Florida include only out-of-state sales. Thus the sum of regional exports by Regions 1,2 , or 3 exceed the value of exports by the state of Florida.

Clam firms in Region 1 had a total of $\$ 14.8$ million in clam sales (direct economic output), $\$ 3.2$ million within the region and almost $\$ 11.6$ million in export sales (Table 5). The total economic impacts of Region 1 include $\$ 24.0$ million in output, $\$ 6.5$ million in labor income, and $\$ 8.8$ million in value added (Table 4$)$. The direct effects accounted for 62 percent of total output impacts, 38 percent of total labor income impacts, and 35 percent of total value-added impacts. The indirect effects represented 19 percent of output impacts, 29 percent of labor income impacts, and 28 percent of valueadded impacts while the induced effects captured 19 percent of output impacts, 32 percent of labor income impacts and 38 percent of value-added impacts.

Clam firms located in Region 2 had $\$ 4.1$ million in total clam sales (direct economic output), $\$ 1.5$ million of which was local sales (within region) and $\$ 2.5$ million represented export sales (Table 5). Total economic impacts of Region 2 include \$5.5 mil- lion in output, $\$ 1.4$ million in labor income, and $\$ 1.9$ million in value added (Table 4). Direct effects captured 75 percent of total economic impacts, 57 percent of labor income impacts, and 53 percent of value-added impacts. Indirect effects represented 13 percent of total output impacts, and 21 percent of labor income and value-added impacts. Induced effects accounted for 15 percent of total output impacts, 21 percent of labor income impacts, and 26 percent of value-added impacts.

Clam firms located in Region 3 generated \$3.0 million in total clam sales, with $\$ 0.2$ million representing sales within the region, and $\$ 2.8$ million in export sales (Table 5). The total economic impacts of Region 3 amounted to $\$ 4.9$ million in output, $\$ 1.4$ million in labor income, and $\$ 1.8$ million in value added (Table 4). Direct effects represented 61 percent of total output impacts, 36 percent of labor income, and 33 percent of value added. Indirect effects captured 22 percent of output, 36 percent of labor income impacts, and 33 percent of valueadded impacts. Induced effects accounted for 16 percent of total output impacts, 29 percent of labor income impacts, and 33 percent of value-added impacts. 


\begin{tabular}{|lccc|}
\hline & Region 1 & Region 2 & Region 3 \\
\hline Local Sales (within region) & & (Million Dollars) & \\
$\quad$ Wholesalers & 2.8 & 0.3 & 0.1 \\
$\quad$ Restaurants & 0.4 & 0.9 & 0.0 \\
$\quad$ Retailers & 0.0 & 0.1 & 0.0 \\
$\quad$ Consumers & 0.0 & 0.2 & 0.0 \\
Total & 3.2 & 1.5 & 0.2 \\
Export Sales (outside region) & & & \\
$\quad$ Within Florida & & & \\
Wholesalers & 2.7 & 0.0 & 0.8 \\
Restaurants & 0.3 & 0.0 & 0.1 \\
$\quad$ Retailers & 0.4 & 0.0 & 0.0 \\
Consumers & $\mathrm{N} / \mathrm{A}$ & $\mathrm{N} / \mathrm{A}$ & 0.0 \\
Out of State, including international & & & 1.3 \\
Wholesalers & 7.9 & 1.0 & 0.2 \\
$\quad$ Restaurants & $\mathrm{N} / \mathrm{A}$ & 1.0 & 0.2 \\
$\quad$ Retailers & 0.2 & 0.5 & 0.1 \\
$\quad$ Consumers & $\mathrm{N} / \mathrm{A}$ & $\mathrm{N} / \mathrm{A}$ & $\mathbf{2 . 8}$ \\
Total & 11.6 & 2.5 & 3.0 \\
\hline Total Sales & & & \\
\hline
\end{tabular}

Table 5. Regional value of cultured clam sales, by destination and marketing channel, 1999.

\section{SUMMARY}

Florida certified shellfish wholesalers that handle Florida cultured hard clams were surveyed to determine the number and value of clams that they process, the sources of their clams, and the marketing channels (wholesale, retail, restaurant, and consumer) where they sell their clams. In addition, the firms were asked the location of their sales. The firms provided the prices they received from different marketing channels by all locations. Unfortunately, the survey was not designed to segregate domestic out-of-state sales from international sales. This resulted in the international sales being aggregated with the domestic out-of-state sales.

Approximately 143 million cultured clams were sold by the Florida clam processing and wholesaling firms in 1999. Northwest Florida (Region 1) handled the largest number of cultured clams (92.3 million). The eastern coast of Florida (Region 2) handled 33.2 million clams and the southwestern portion of the state (Region 3) handled 17.6 million. The firms obtained their clams from within their own region as well as from the other two regions in Florida. Most of them came from either personal leases (20 percent) or other growers ( 73 percent).
The survey results indicate that the Florida clam industry is spread out over a number of firms of varying sizes. The smallest firm handled only 2,000 clams and the largest handled almost 25.5 million clams. The Florida clam industry is made up of a number of small firms and the market share, or percent sold by any one firm, was relatively small, typically under 5 percent.

The Florida cultured hard clam wholesale and processing industry had $\$ 21.8$ million in sales in 1999. Around 43 percent of these sales were within the state and 57 percent of them were to out-of-state locations, including international destinations. Regardless of the geographic destination of the cultured clams sold by clam firms, the majority (78 percent) were sold to other wholesalers.

The total economic impact of the clam industry on Florida, after accounting for direct, indirect, and induced impacts, was $\$ 33.9$ million in output, $\$ 9.0$ million in labor income, and $\$ 12.1$ million in value added. The total economic impacts were also calculated for each region. In Region 1 the clam industry generated a total of $\$ 24$ million in output, $\$ 6.5$ million in labor income, and $\$ 8.8$ million in value added. In Region 2, the total economic impact of the 
clam industry was $\$ 5.5$ million in output, $\$ 1.4$ million in labor income, and $\$ 1.9$ million in value added. In Region 3 the total economic impact was estimated to be $\$ 4.9$ million in output, $\$ 1.4$ million in labor income, and $\$ 1.8$ million in value added.

\section{OUTLOOK}

The hard clam culture industry represents a sizeable economic contribution to the economy of Florida, and to the local economies where the production and marketing activities occur. This analysis should provide useful information to those interested in monitoring the development of this new industry. Further growth in the economically important hard clam culture industry will likely be linked to a number of environmental, production, and market-related factors. For example, the maintenance or enhancement of coastal water quality within growing regions in Florida will need to be ensured, an objective that will be increasingly challenging as coastal development increases. Further development of local, regional, and national markets for Florida cultured hard clams will need to be achieved. Assuring the traditional high quality of Florida cultured clams through the use of alternative on-board and shore-side handling methods will continue to be a priority issue, and will assist greatly in market development efforts. In addition, finding ways to reduce production costs and increase production efficiency will enhance profitability of growers. Reducing production risk by utilizing recently implemented USDA crop insurance programs will allow growers to better plan for the uncertainty that characterizes the culture of any aquatic organism within the natural environment. Careful attention to each of these factors will provide support for continued growth in the cultured hard clam industry, which has so quickly grown to be an important source of economic activity in Florida's coastal communities.

\section{LITERATURE CITED}

Adams, Charles and P.J. van Blokland. 1995. "Economic and Financial Considerations Regarding the SmallScale Commercial Culture of Hard Clams in the Cedar Key Area of Florida," Staff Paper Series, Food and Resource Economics Department, IFAS, University of Florida, $27 \mathrm{p}$.
Florida Agricultural Statistics Service. 2000. "Florida Aquaculture," $4 \mathrm{p}$.

Miller, R.E. and P.D. Blair, 1985. Input-Output Analysis: Foundations and Extensions. Prentice-Hall, Englewood Cliffs, New Jersey, 464 p.

Mulkey, W.D. and A.W. Hodges. 2000. Using IMPLAN to assess local economic impacts, University of Florida Extension FE 168. http://edis.fas.ufl.edu. 


\section{Appendix}




\section{UNIVERSITY OF} FLORIDA

Florida Sea Grant College Program

The State University System Program for

Coastal Research, Education and Extension
Marine Economics Program

1123 McCarty Hall / P.O. Box 110240

Gainesville, FL 32611-0240 USA

Phone: (352) 392-1826, Ext. 223

FAX: (352) 392-3646

Suncom: (352) 622-1826

E-Mail: ADAMS@fred.ifas.ufl.edu

22 September 00

Dear

The cultured clam industry is recognized as the fastest growing component of the food fish aquaculture industry in Florida. A recent Florida Agricultural Statistics Service survey (copy attached) shows that farm-gate sales of cultured clams was almost \$16 million during 1999, an increase of about 200\% over 1995 sales.

Continued growth of your industry requires support such as reasonable water quality standards, favorable permitting and regulatory measures, effective marketing efforts, and a focused University-based extension program. To ensure that the industry receives the support it deserves, state and local decision-makers need to understand the importance of cultured clam sales to the Florida economy. Though it is no secret to you, sales of cultured hard clams provide new dollars, jobs, and incomes to the local community where you do business. Unfortunately, these contributions have never been documented.

The purpose of the enclosed survey is to collect the information necessary to document the importance of the hard clam industry to your community and Florida. Please note the enclosed survey form. We will be calling you within the next few days to conduct the survey over the telephone. The attached brief survey has been sent to you so that you can familiarize yourself with the information we will be asking you to provide. The telephone interview will require only about 10 minutes and the information is critical for describing the economic importance of the new, growing cultured clam industry.

Notice that we are asking you to provide estimates on your 1999 clam sales. However, the more accurate your responses, the better we can document the importance of your industry. So, please look over the enclosed survey form completely. Fill it out ahead of time if possible. We will contact you by telephone soon to collect the information. Again, our phone call will be brief.

The information you provide will be averaged with everyone else's, such that each firm's information is anonymous.

If you have any questions, please do not hesitate to contact either of us at the telephone (or email) numbers provided below.

Thank you in advance for your assistance in this brief survey. Without this information, the importance of your industry will continue to remain unknown to those who need to know. We will be contacting you soon. Thanks again.

\section{Sincerely,}

Chuck Adams

Marine Economics Specialist

352-392-1826, ext. 223

adams@fred.ifas.ufl.edu

\author{
Leslie Sturmer \\ Multi-County Aquaculture Extension Agent \\ 352-543-5057 \\ LNST@gnv.ifas.ufl.edu
}




\section{CULTURED HARD CLAM MARKET CHANNEL ASSESS- MENT FOR 1999}

The primary purpose of this survey is to determine where Florida-grown cultured hard clams are sold, to whom, and for how much during 1999.

\section{A. LOCATION OF CERTIFIED FIRM -}

1. Did your business have multiple certified shellfish processing plants during 1999 ?

$$
\mathbf{Y} \longrightarrow \mathbf{N}
$$

2. In what regions (see map below) were your certified shellfish processing plant(s) located during 1999 ?

$$
\text { I }
$$

II III

(Please answer questions $B, C$, and $D$ with respect to plants located in each region.)

\section{B. NUMBER AND SALES OF CULTURED CLAMS SOLD -}

1. What was the total number (estimate across all sizes) of Florida-grown hard clams you processed and sold during 1999 ? clams

2. What was the total sales value (estimate across all sizes) of Florida-grown hard clams you processed and sold during 1999?

\section{Florida Region Map}

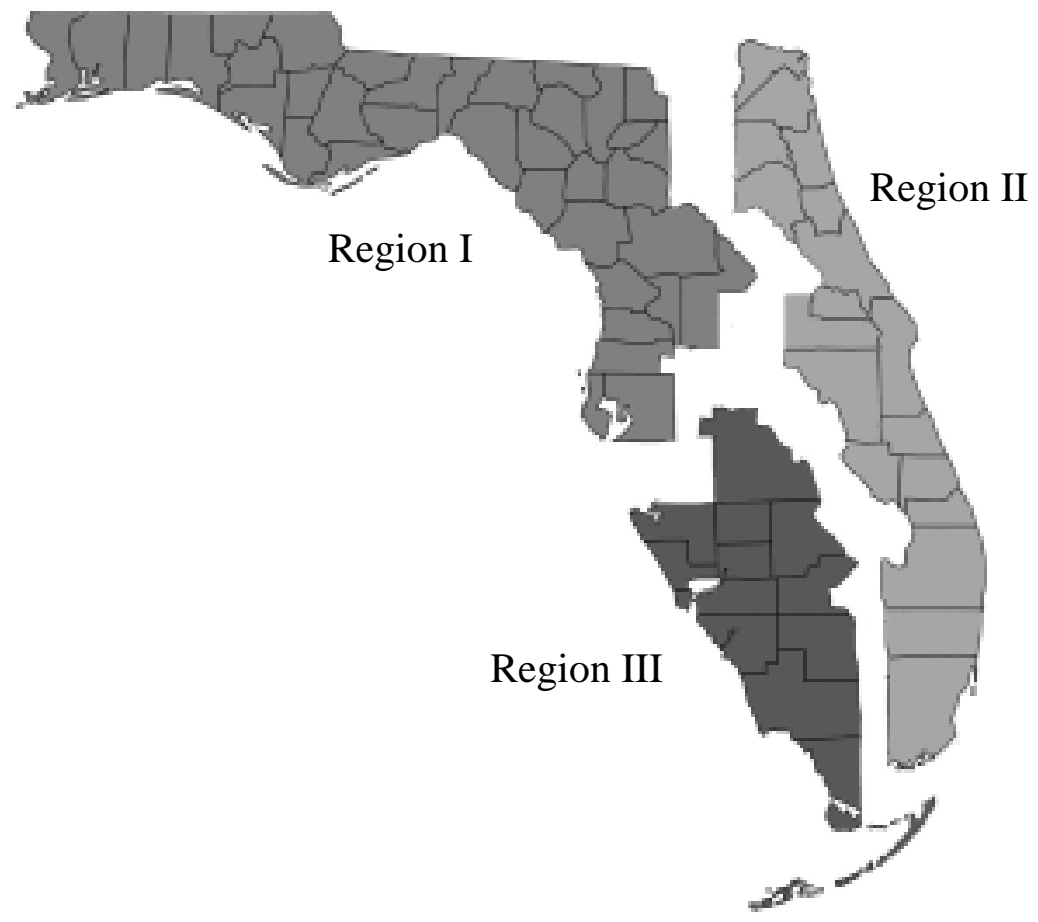




\section{ORIGIN OF CULTURED CLAM SUPPLY -}

$\begin{array}{ll}\text { Consider THREE sources of clams ---> } & \text { Your Lease(s) } \\ \text { Other Growers } \\ \text { Wholesalers }\end{array}$

1. Of the total number of clams you processed and sold in 1999, how many were obtained from the following sources:

Your Lease(s)
Other Growers
Wholesalers

(Total should add up to answer for question B. 1.)

2. Of those clams obtained from Your Lease(s), what percent were grown on leases in each region?
I $\%$
II $\%$ III $\%$

3. Of those clams obtained from Other Growers, what percent were obtained from growers in each region?
I $\%$
II $\%$ III $\%$

4. Of those clams obtained from Wholesalers, what percent were obtained from wholesalers in each region?

I $\%$

II $\%$

III $\%$ 


\section{DESTINATION OF CULTURED CLAM SALES -}

The following questions ask for volume and price information. Price may vary by size of clam, time of year, order quantity, etc. Please provide only an average price (including all shipping costs) by type of buyer where possible.

\section{Consider four destinations of clams you sell ---> Inside your region Outside your region ... but in Florida Outside of Florida ... but in USA Outside of USA}

1. Of the total number of clams you processed and sold in 1999, how many were sold to buyers in the following locations?

\section{Inside your region}

Outside your region ... but in Florida

Outside of Florida ... but in USA

\section{Outside of USA}

\section{(Total should add up to answer for question B. 1.)}

2. Of the clams sold Inside your region, who did you sell them to?

Other wholesalers

Restaurants / food service

Retail Seafood Shops

Direct to consumers

$\% \quad$ Average Per Each Price

3. Of the clams sold Outside of your region ... but in Florida, who did you sell them to?

Other wholesalers

Restaurants / food service

$\% \quad$ Average Per Each Price

Retail Seafood Shops

Direct to consumers

4. Of the clams sold Outside of Florida (including international sales), who did you sell them to?

Other wholesalers

$\%$

Average Per Each Price

Restaurants / food service

Retail Seafood Shops

Direct to consumers 
List of Counties in Each Region

\begin{tabular}{ll}
\hline Region 1 & \\
\hline Alachua & Lafayette \\
Baker & Lake \\
Bay & Leon \\
Bradford & Levy \\
Calhoun & Liberty \\
Citrus & Madison \\
Columbia & Marion \\
Dixie & Okaloosa \\
Escambia & Pasco \\
Franklin & Pinellas \\
Gilchrist & Santa Rosa \\
Gladsden & Sumter \\
Gulf & Suwannee \\
Hamilton & Taylor \\
Hernando & Union \\
Hillsborough & Wakulla \\
Holmes & Walton \\
Jackson & Washington \\
Jefferson &
\end{tabular}

\begin{tabular}{l}
\hline Region 2 \\
\hline Brevard \\
Broward \\
Clay \\
Dade \\
Duval \\
Flagler \\
Indian River \\
Martin \\
Nassau \\
Okeechobee \\
Orange \\
Osceola \\
Palm Beach \\
Putnam \\
Seminole \\
St. Johns \\
St. Lucie \\
Volusia
\end{tabular}

Region 3

Charlotte

Collier

Desoto

Glades

Hardee

Hendry

Highlands

Lee

Manatee

Monroe

Polk

Sarasota 


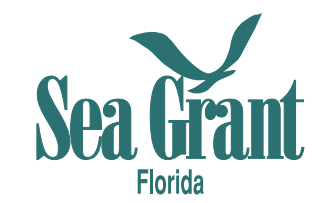

Science Serving Florida's Coast

For Florida's 15.5 million residents and about 50 million annual visitors, the coast and its resources are a major attraction and an important part of their environment. Nowhere else in the United States are so many people so close to such an extensive and economically valuable coastline.

Working together, all Floridians must find a socially acceptable way to satisfy the demand for these resources while protecting their ecological integrities. Florida Sea Grant has a vital role to fill in this complex endeavor. Florida Sea Grant's mission is to enhance the practical use and conservation of coastal and marine resources to create a sustainable economy and environment. Now in its $30^{\text {th }}$ year, Florida Sea Grant is the only statewide university-based coastal research, education, extension/outreach and communications program in Florida. One of 30 Sea Grant programs nationally, it is a partnership program among the National Oceanic and Atmospheric Administration, Florida's universities and Florida's citizens, businesses and governments.

Florida Sea Grant has a demonstrated record of success. Its program of research, education and extension earned a rating of "Excellent" from a federally mandated review by the National Sea Grant College Program in 2000. We invite you to learn more about Sea Grant's contributions and its leadership role in helping Floridians to rationally manage continued growth in the coastal zone by reading the 2002-2005 Florida Sea Grant College Program Strategic Plan, available by visiting the Florida Sea Grant web site at:

http://www.flseagrant.org. 


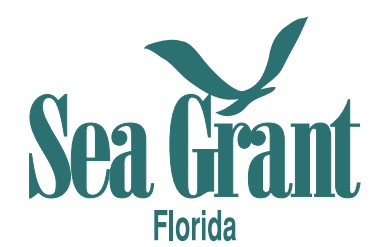

Science Serving Florida's Coast Florida Sea Grant College Program PO Box 110409

University of Florida

Gainesville, FL 32611-0400

(352) 392-5870

www.flseagrant.org 